$J J M L L$

\title{
Post-Heroic Portrayal of War in Kevin Powers' The Yellow Birds
}

\author{
Raihanah M. M. \\ Faculty of Social Sciences and Humanities, National University of Malaysia, Malaysia
}

M. Ikbal M. Alosman*

Department of English Language and Literature, Dhofar University, Oman

Received on: 20-9-2020

Accepted on: 4-1-2021

\begin{abstract}
Kevin Powers is a war veteran, who employs his experience as a war veteran in the American army in Iraq from 2004 to 2005 to narrate his debut novel, The Yellow Birds (2013). This study investigates Powers' portrayal of post-heroism in the context of the Second Gulf War. This novel illustrates the deformed face of war within an emerging post-heroic atmosphere. Post-heroism, instead of bravery and chivalry, signals the decline of heroic ethos in the context of war, in which soldiers are left to question the true value of sacrifice in the battlefield. The narrative's battlefield imagery, emotive repercussions of those involved and motives of war are examined by referring to the soldiers' post-heroism. Albeit war is personified as a looming figure at the onset of the narrative, Powers' post-heroic narrative leaves little doubt of the futility of engaging with war.
\end{abstract}

Keywords: Kevin Powers; War on Iraq; Post-Heroism; The Yellow Birds; War Narrative.

In Kevin Powers' The Yellow Birds (2013), Private John Bartle recounts the story of his service in the US Army in Al Tafar, Iraq, with his colleague, Private Daniel Murphy (Murph). The two soldiers served under Sergeant Sterling. The narrative goes back and forth between Iraq and the present-day America. As a war veteran, Powers draws on his experience as a machine gunner in the American Army in Iraq from 2004 to 2005. Theo Tait (2013) commented that The Yellow Bird appears to echo renowned American war narratives of the 20th century, including Ernest Hemingway's Farewell to Arms (1929), Norman Mailer's The Naked and the Dead (1948) and Tim O'Brien's The Things They Carried (1990). Ron Charles (2012), a Washington Post reviewer, situated The Yellow Birds within the post 9/11 American canon alongside such established novelists as John Updike, Don DeLillo, Andre Debus III and Lorrie Moore. Although Powers is recognised as an emerging voice in the American literary landscape, he has distinguished himself as a war novelist through his ability to communicate the immutable horrors of war and the indelible scars it leaves behind (Nester 2013).

The current study considers Thomas Nester's (2013) contention that Power's novel should be read by Americans to recognise the ruthless face of war and problematises one facet of the war narrative,

\footnotetext{
๑ 202 JJMLL Publishers/Yarmouk University. All Rights Reserved,

* Doi: https://doi.org/ 10.47012/jjmll.14.1.10

*Corresponding Author: meqbal1980@yahoo.com
} 
namely, the issue of heroism. Although heroism is highly regarded in terms of self-sacrifice and bravery, the reason behind such a sacrifice is questioned more than ever in today's warfare (Luttwak 1995; Coker 2002; Coker 2014; Scheipers 2014). From a post-heroic perspective, battlefields are no longer the sights where heroic acts are desired and celebrated. The current research investigates the representation of postheroism in The Yellow Birds by considerably studying the three signifiers, namely, the sight of war, frame of mind and motives of war.

Hemingway (1979, xiv) is one of the most distinguished war novelists who asserted that 'a writer's job is to tell the truth. His standard of fidelity to the truth should be so high that his invention, out of his experience, should produce a truer account than anything factual can be'. Lisa Tyler $(2001,22)$ observes from Hemingway's representation of war that the value of the 'concrete' is indicative of his emphasis on the narrative that moves beyond a depiction of life, rather than one that 'make[s] an experience come alive for the reader'. Similarly, veteran soldiers continue to mould their experiences into literary works with a desire to concretise their experience and realign their roles in the society. Frank Usbeck $(2018,2)$ states that veterans who engage in such an exercise do so 'as a means of reintegration [...] they both nurture public discourse on war and pursue concrete results for individual veterans' well-being'. Powers is one such veteran, whose debut novel has created equally critical and engaging reviews.

In The Yellow Birds, Powers 'communicates what even Tim O'Brien seems not to understand about America's new wars' (Hawkins 2014, 96). Many American veterans know that few civilians in the United States want to be held responsible for current wars. Powers guides readers to gain access to the realities of war by focusing on Bartle's memories (Walter 2016). Bartle inadvertently gets alienated from his own culture whilst internalising the terrible truths of modern war (Hawkins 2014). He becomes a victim of the violence of war, the American public and political deception (Mann 2016). Repetitive sights of death have shattered Bartle's potential perception of an intrinsically collective humankind (O'Gorman 2015). His 'eidetic memories' emphasise horror, which connects the bodily and psychological fatalities of the war to September 11 (Mann 2016, 4). The idea of guilt encompasses the narrative's demonstration of war (Nester 2013). Bartle's feeling of guilt is an all-pervading shadow driven by the awareness of 'the disintegration of any trace of humanity' (Precup 2017, 188). He attempts to reassert the prospect of 'human connectedness' to counter the cruelty of the war (Precup 2017, 188).

Powers' insight into the demesnes of war in Iraq is the subject of ongoing examination. Even though his novel received considerable attention from a wide spectrum of reviewers and literary critics, his depiction of war from a post-heroic perspective should be considered to comprehend the narrative's due significance. This research aims to illustrate the narrative's post-heroic portrayal of war, given that wars are being waged needlessly. This study also intends to lead readers to appreciate the narrative's condemnation of war and strive for minimally damaging means to settle disputes.

\section{Methodology of Analysis: Post-Heroism in Narrative}

In the previous two decades, 'western societies entered a post-heroic era,' in which the cost on human lives outweighs the value of sovereignty over other nations (Scheipers 2014, 1). In his influential 
Foreign Affairs article, the American strategist Edward Luttwak (1995) popularises the term 'post-heroic warfare' to accentuate Western societies' diminishing interest for armed conflicts and war-related selfsacrifice in place of bloodless geo-economic rivalries (Luttwak 1995). Within the context of the US, the decline in support for participation in war by the American citizen dates back to the beginning of the 20th century (Scheipers 2014). Thus, although military intuitions are as sturdy as before, they are challenged by strong oppositions from within the country (James 1971). The rationale behind wars is questioned as people become considerably acquainted with its unspeakable realities.

Heroism at its root is defined by acts of courage and valour in the face of great uncertainty and risks. An important dimension in the politics of war is related to the construct of heroism, which critics have noted to be no longer appealing to the mass (Ryan 2014). Scheipers $(2014,3)$ defines a hero as someone who sacrifices his/her life for a cause that has 'a common good of a higher order'. Given that 'heroism feels and never reasons' (Emerson 1908), this concept is irrational and counterproductive (Ryan 2014). Heroism is 'indifferent to prudential appeals [...] as it is indifferent to the judgments of others in general' (Ryan 2014, 123). Moreover, heroism is naïve because the 'indifference' is rooted from 'a general lack of self-reflection' usually associated with 'youth, innocence and spontaneity' (Ryan 2014, 123).

Subsequently, the general perception of war is changing with soldiers' reviewing their ethos over the last few decades (Coker 2002). Societies no longer celebrate death or injury in war; they strive to avoid causalities (Coker 2002). Scheipers $(2014,2)$ contends that 'the extent to which the assumption of a "post-heroic condition" in western societies and their aversion to casualties in war has become accepted as common knowledge in policy circles and political commentary is striking'. Death in the battlefield is less meaningful than it used to be. Loss of life becomes a waste and heroes are now considered victims (Coker 2007; Scheipers 2014).

The approach to war from a realistic perspective was not perceived positively until recently. Jane Addams, a Nobel Peace Prize laureate, was shocked by what she witnessed when she travelled to Europe after the outburst of aggression of the First World War to observe the related events (Ryan 2014). When she returned to New York, she described how soldiers were provided with alcoholic drinks before major encounters (Ryan 2014). Although she was not speaking about American soldiers, she was immediately disparaged in the newspapers (Ryan 2014). Those who narrated wars were obliged to embellish all the unspeakable realities in the battlefield and make the conflicts appear heroic and idealistic. John Lynn $(2009,361)$ asserts that 'For a number of reasons, the discourse of war tries to modify reality to more nearly resemble conceptions of how war should be'. The analysis in Powers' The Yellow Bird illustrates that this tension between reality and construct of war is manifested in the internal conflicts faced by the three central characters, namely, Private Bartle, Private Murphy and Sargent Sterling. This internal conflict is also represented by soldiers with actual experience of brutality.

What a soldier witnesses in the battlefield may re-evaluate his view of war regardless of the acknowledged incentives. Hence, the motivations are the root cause of him being a soldier. Philosophers, including Hobbes, Locke, Hegel and Kant, agree that 'the assumption that the reasons for which soldiers fight are very important' (Ryan 2014, 131); 'They must cohere with the other kinds of reasons that 
motivate them as rational individuals, and they must cohere with the other kinds of roles they occupy as members of society'(131). The justification of a soldier's deeds in war starts with the motives that rationalise their country's participation in war (Ryan 2014). Ryan $(2014,132)$ contends that soldiers should question the motives behind their acts and whether they are well-suited with this peculiar 'selfrespect'; killing in war and dying in war are 'interconnected' (132). Killing for nation, principles and relatives equals dying for them.

In The Yellow Birds, Private Bartle relates the story of his service in the US army in Iraq with his colleagues, Sargent Sterling and Private Murph. The non-lineal plot line oscillates between December 2003 and April 2009. The narrative moves retrospectively amongst Iraq, Germany and America. We investigate three primary issues to grasp the narrative's illustration of war: (1) what is observed by the soldiers, (2) what it feels like to be there and (3) how war affects their psychology and emotions. The three constructs provide the general, public and personal aspects of war. Firstly, scenes from the battlefield are illustrated within their post-heroic context in 'the sight of war.' Secondly, the emotive repercussions of war are discussed in the section titled 'frame of mind'. Thirdly, in 'motives of war', the discussion focuses on how war is rationalised to avoid psychism in the mind of those who participate in it.

\section{Analysis}

\section{The Sight of War}

The title of Powers' The Yellow Birds is derived from a traditional cadence in the American Army that is also used as a prelude to the novel. The lines foreshadow the unnecessary brutality that will unfold as the narrative takes the reader through the experience of being at war:

A yellow bird

With a yellow bill

Was perched upon

My windowsill

I lured him in

With a piece of bread

And then I smashed

His fucking head... (Quoted in Powers 2013)

The poem used in the context of this story personifies war as a person who 'lures' the soldiers with something they desire only to heartlessly kill their mind, body and soul. The theme in this poem is echoed in the story, in which war is personified as a ruthless monster who preyed on the soldiers' weakness: 'While we slept, the war rubbed its thousand ribs against the ground in prayer. When we pressed onward through exhaustion, its eyes were white and open in the dark. While we ate, the war fasted, fed by its own deprivation. It made love and gave birth and spread through fire' (Powers 2013, 3). The soldiers are shown to be at the mercy of war. 
The soldiers' vulnerability is an important theme in this novel. Given the changing seasons, the one constant in the soldiers' experience at 'the plains of Nineveh' in Al Tafar, Iraq, where the fighting is set is that they are fighting for their survival. The opening paragraph of Chapter 1 echoes this theme of vulnerability with the line, 'THE WAR TRIED to kill us in the spring' (Powers 2013, 3). The second paragraph continues the same tone with the line, 'Then in summer, the war tried to kill us as the heat blanched all color from the plains' (3). The opening scene juxtaposes the changing of seasons and the colours of life with the impending doom that awaits the soldiers as they continue to fight in the battlefield, 'It tried to kill us every day. ... We were not destined to survive' (3-4). The war's untiring effect continues through day and night: "While I slept that summer, the war came to me in my dreams and showed me its sole purpose: to go on, only to go on. And I knew the war would have its way' (4). Thus, the post-heroic theme of fighting for their survival instead of courageously fighting a foe is made acute in the narrative.

Connected to the theme of survival is the rampant instances of death. Death appears to be the most influential factor throughout the narrative's illustration of war. In war, life is 'rare', whereas death is abundant. Malik, the Iraqi translator, gets shot whilst Private Bartle and Private Murph have a conversation with the former. Even though Privates Bartle and Murph see 'his blood' on their uniforms, they are ambivalent about his passing. Bartle recounts the equivocation with which he accepts Malik's death; 'I was not surprised by the cruelty of my ambivalence then. Nothing seemed more natural than someone getting killed' (Powers 2013, 11). The frequency, reality and actuality of death make such an event a normal incident. Given the circumstances, death is normalised and quantified as a number. When Malik gets killed, Murphy asks Bartle a critical question, 'Doesn't count, does it?' Malik, being an Iraqi, did make the list of casualties who suffered from the Americans. Bartle replies, 'No. I don't think so.' Powers convey the important dimension to post-heroic warfare through this episode, in which the thought of survival becomes the primary focus for the soldiers. Just as 'The war desires nothing more than to go on, to continue killing and corrupting' (Nester 2013, 40), the soldiers want nothing more than to survive. The theme of survival is reiterated when Bartle candidly recounts the death of 19-year-old soldier named Miriam Jackson: 'We were glad. Not that she was killed, only that we were not' (Powers 2013, 13).

Another dimension to the theme of post heroism is the way the narrative concretises the daily reality faced by the soldiers. The odour of death pervades in the entire city of Al Tafar. The smell of death is also accompanied with the odour of sewage that accentuates the loathsome, disastrous situation and the overall decay of the ancient city of Al Tafar. As Bartle recalls, '[t]he stench of the dead had cut itself free from the other odors coming from Al Tafar. The trash fires and sewage, the heavy scent of cured lamb, the river; above all this was the stink of decay from the bodies themselves' (88). Powers adds another dimension to the post-heroic discourse by showing how a life at war ends in the sewer. Thus, the Iraqis and Americans are equal victims of the same war when death overcomes them. Death in this context is not the honourable end of a brave fight but an abominable scene of misery and dishonour.

The lack of reverence shown to the human body is another aspect of post-heroic warfare, in which the body is transformed from a life-carrying vessel to a bomb carrying one. In war, human bodies are 
used as '[b]ody bomb[s]' (Powers 2013, 124). In one scene, we are shown how a human body is sprawled on a bridge with his head cut and laid on his chest. His guts are removed and stuffed with explosives. Bartle envisions how this man must have begged them to release him as they 'cut his throat' (127). Such a man is made 'an unwilling weapon' (127). Animals are also turned into bombs, 'the husks of dogs filled with explosives' (145). Powers' post-heroic narrative illustrates how people and animals are exploited during times of war with little regard for their rights and values.

Another aspect of the callousness of war is its blindness to the victims and its inconsiderate vigour to kill people regardless of age or gender. Sterling fires his machine gun on an approaching car until the holes made by the gun machine becomes 'funnelled light' (22). An elderly woman falls from the car and attempts to drag herself to the side of the road; '[s]he crawled. Her old blood mixed with the ash and dust' (22). Although the innocent woman is dead, "[t]here was no grief, or anguish, or joy, or pity in that statement' (22). Thereafter, Sterling shares a 'dry cake' with Bartle and Murph as if nothing significant has just taken place. The effects of war continue to dehumanise the soldiers into killing first and thinking or even feeling later. David Livingston Smith $(2011,13)$ states that the dehumanisation of soldiers 'acts as a psychological lubricant dissolving our inhibitions and inflaming our destructive passions... it empowers us to perform acts that would under other circumstances, be unthinkable'. However, in the case of Murphy (as discussed later), his inability to dehumanise himself from his act of killing finally leads him to lose his sanity.

Powers offers his readership sketches of an antagonistic nature instead of portraying the warring armies and their feats on the ground. In the groves of Al Tafar, Bartle and his colleagues in the platoon hear a sound of 'weeping; closer, a bleating lamb' (Powers 2013, 118). Bartle recounts,

the enemy dead strewn about a shallow ditch: two boys, sixteen or so, their battered rifles lying akimbo at the bottom, had been shot in the face and torso. Their skin had lost most of its natural brown, and [...] their blood had congealed in pools at the bottom of the ditch. (118)

Bartle mockingly describes the two boys as their enemies to reiterate the inhuman aspect of war, in which children participate in such horrible events and are attacked as enemies. Powers likens the boys' weeping to bleating lamb to stress their innocence and vulnerability. By portraying the scene of the boys' tragic death and the blood pools around them, Powers reveals another hostile face of war, in which children are participants and victims of war as well.

As war continues, being alive is considered bliss (Powers 2013). Bartle confesses his happiness when they have learned that a female soldier was killed in a mortar attacks in Samarra, "We were glad. Not that she was killed, only that we were not' (13). For soldiers in the post-heroic era, the anticipated glory of a dead soldier is not a valid or certain reality (Ryan 2014). Death in war is no longer conceived as an act of heroism in Western societies (Smith 2005). Rather than revering dead soldiers as 'heroes', people in recent times regard their bereavement as a 'waste' (Scheipers 2014, 1). Past heroes become today's victims (Coker 2014; Scheipers 2014). Accordingly, the notion of inscribing the names of killed soldiers on munitions indicates war's destructive and endless nature. 
Throughout Bartle's illustration of the war in Iraq, the images of raging 'fire' appear repetitively in the narrative (Powers 2013, 3, 10, 11, 14, 16, 17, 18, 63, 75, 84, 85, 88, 90, 95, 116, 117, 118, 119, 124, 126, 200, 210, 211). After being lively before the war, orchards in The Yellow Birds are generally in flames or are 'burning' (17). These orchards are turned into a sign of death. Additionally, human 'bodies' also burn $(5,23)$. The recurring images of the burning orchards and bodies accentuate war as a destructive machine and not the sight of heroic acts. Consequently, the existence of war depends on the death and destruction of those who are willingly or compulsorily involved.

Another ghastly aspect of war is its negative influence on soldiers, given that such a conflict makes them merciless murderers and not glorious warriors. Bartle recounts how an Iraqi insurgent who runs behind a low wall is 'astonished to be alive, his weapon cradled in his arms' (Powers 2013, 20). Bartle's 'first instinct was to yell out to him. You made it, buddy, keep going' (20). However, he remembers 'how odd it would be to say a thing like that' (20-21). After the Iraqi man is discovered by Bartle's colleagues, Bartle confesses that he "wanted to tell them to "stop shooting at him", to ask, "What kind of men are we?"' (21). He sympathises with the Iraqi man because both of them are 'frightened' (21). Amidst Bartle's confusion, he realises, 'with a great shock' that he has been shooting at the same man with his colleagues until the Iraqi man is 'dead' for sure' (21). Thereafter, he feels better as he recognises that they have killed the man 'together' and he is not sure 'who did it' (21). Although Bartle never enjoys death scenes as some does, he watches passively when civilians are gunned down; the war is to blame (Nester 2013). Heroes no longer possess that 'grandiose' they used to have; instead, they are considerably passive and compassionate (Coker 2014,69). Such a conflict within Bartle's psyche uncovers the contradiction between his personality as a kind-hearted man, who wants to save the Iraqi man and his position as a soldier who is supposed to kill.

An important aspect of post heroism is how the battlefield becomes not the sight of chivalry and nobility, rather where cruelty excels and prospers. Although Bartle expresses his hate for the manner by which Sterling 'excelled in death and brutality', he confesses the necessity of these attributes in war (Powers 2013, 19). He describes how Sterling's scream into his ear, 'Shoot these hajji fucks!', brings him to return fire and kill more people; 'seeing him [Sterling] shooting too, smiling the whole time, screaming, the whole rage and hate of these few acres, alive and spreading, in and through him' (19-20). Out of 'rage' and 'hate', such acts of murder continue to claim numerous lives to feed the war machine. Brutality becomes normal because killing is the most significant theme in the post heroic war narrative.

\section{Frame of Mind}

In The Yellow Birds, death is a looming ghost that conquers the psyche of soldiers. Fear of death dwells their every moment as they watch it looming around (Coker 2014). Bartle recounts how, throughout the days of combat, they have crawled and curled themselves 'into absurd shapes and huddled below the whitewashed walls of our position. We stayed awake on amphetamines and fear' (Powers 2013, 5). Bartle also recounts how the lieutenant looks 'scared and tired' (90). Such images of war are not the

ideal ones on unbelievably courageous soldiers with grand achievements. Instead, Powers prefers to 
recount the battlefield from a realistic perspective, in which soldiers are overcome with the reality of death around them and they take brain stimulators and amphetamines to keep up with the lethal situation. American soldiers are preoccupied with their return to the US and living an 'ordinary life' in the country (Mathonniere 2014, 7). Instead of war sceneries of courage and bravery, soldiers are obsessed with their fear of death and their survival instincts to stay alive.

An element of post-heroism can also be seen when soldiers are described with an overwhelming sense of panic and anxiety. Under mortar attacks, Bartle confesses, 'I gave up, surrendered, whatever, I was gone' (Powers 2013, 167). He does not know where to go or what to do whilst obsessed with 'fear' (168). He cries, 'sob[s]' and 'wet[s]' his pants (168). He hides under 'shit water', where only his nose and eyes are above water until the mortars attack stops (169). Instead of creating a heroic scene, Powers relates Bartle's reactions realistically, in which he declares his total frustration and despair. Additionally, Powers illustrates the concealed realities of war, in which soldiers are primarily concerned with their own mortality. In one episode, Bartle witnesses the final moments of a private's life, "his teeth chattering, mewling like a lamb." (Powers 2013, 118) He waits for the dying soldier to say something like that, "in the movies,' before he dies (Powers 2013, 120). The dying private continued to cry as he asks his sergeant, “'I'm fucking dying, right?" (120) In Powers' war narrative, soldiers are shown to die with a desperate yearning for survival. In a sad and wretched manner, their fear appears to lead them to their grave. And what is equally pitiful is that their death is not celebrated but pitied by those around them.

Sadness is not exclusive for American soldiers in Iraq; Iraqis are also depicted as miserable because of war. Bartle recounts that they 'could hear a soft keening while [they] watched the low hills and desert glimmer in the darkness' (Powers 2013, 84). As Bartle, Murph and Sterling listen to a noise coming from a nearby orchard, Bartle thinks that 'it seems wrong not to listen [...] There was something both ordinary and miraculous about the strange wailing that we heard, and the way it carried to us on the wind that began inside the orchard' (85). Listening to the wailing of those who have lost their dear ones is the message of the wind to the American soldiers. The saddening sound conveys the sufferings of the Iraqi people from the ongoing war and is meant to be heard by the American soldiers. For Powers, listening to the sufferings of the Iraqi people is not wrong. However, the failure to consider the Iraqis' denunciation of and complaint about war is erroneous.

An important feature of the post heroic narrative is the shame felt by the soldiers. Fighting at war is shameful and recalling the unnecessary killings of innocent people is stressful. When Bartle returned to the United States, people would greet him and show respect to his service in the army. His first encounter is at the airport, where he awaits the connecting flight home. Bartle stops at the airport bar for a drink. The barman offers him a drink for free as a token of appreciation for his service to the country. This gesture leaves Bartle feeling uneasy and defensive. In another instance, the pilot announces that he is 'honored' to give 'an American hero a ride home' (107) Bartle again feels uncomfortable and anxious. He recounts his lack of heroism, focusing on nothing 'except survive' (107); 'I [am] no hero, no poster boy, I [am] lucky to get out upright and breathing' (180). Bartle's reluctance to be praised for his participation illustrates Powers' narrative emphasis on the realistic face of war, in which soldiers, unlike heroes who 
return and recount their stories of bravery and valour, are left feeling impotent for wanting only to dodge the bullet.

Furthermore, Bartle believes that he does not deserve the people's 'gratitude' for being in Iraq as an American soldier (Powers 2013, 144). Instead, he believes that people should 'hate' him for that; 'everyone loves me for it and it's driving me crazy' (144). For Bartle, participating in a cruel war is not a heroic act that should be celebrated. The people have not seen what he has witnessed and experienced in Iraq. He wonders if he should tell these people that he wants 'to die' and to commit suicide because of what he has seen and done in Iraq. The reason is that, 'there isn't any making up for killing women or even watching women get killed, or for that matter killing men and shooting them in the back and shooting them more times than necessary to actually kill them and it was like just trying to kill everything you saw sometimes because it felt like there was acid seeping down into your soul and then your soul is gone...' (144).

Bartle, who has been taught throughout his life that there is no "making up" for what a man does, is astonished how his mother like everyone else is 'so happy and proud' because her son has made people 'crumple' until they are motionless (Powers 2013, 144). Bartle recounts how happy his family and friends are to see him, 'the murderer' (145). Burdened with the memories of war, Bartle starts 'crying' (146). Bartle is engrossed with his guilt and believes that redemption is impossible because the evils he has committed and witnessed are so immense and intolerable. His experience at Al Tafar, Iraq, leaves him with the realization that war is not a place where people ascertain their gallant qualities or morals but an immoral landscape of sin and sinners.

Through this narrative Powers demonstrates the influence of war on social relations. The narrator, Bartle relates how he does not think substantially about Malik after the latter's death in front of his eyes. Malik is only 'an incidental figure who only seemed to exist in his relation to my continuing life' (Powers 2013, 12). Bartle recounts how he has been trained to believe that 'war is a great unifier for people than any other activity on earth' (12). Nonetheless, after being personally engaged in war, he confesses that '[w]ar is the great maker of solipsists [egoists]: how are you going to save my life today? Dying would be one way. If you die, it becomes more likely that I will not' (12). Accordingly, the death of Bartle's companions signifies his survival. Their lives are a necessary offering for the ongoing war and serve as guarantee for his life. Murph in another episode says that he is 'happy' because he did not die but someone else did (121). The post heroic stance presented in The Yellow Bird signals the reality of war; The death of others is preferred because of its abundance and the rarity of life. War makes people considerably selfish as they struggle to avoid death by perceiving the death of their war comrades as a guarantee for their own lives.

\section{Motives of War}

An aspect of war that occasionally goes unrecognised is the public face that is shown to justify such a conflict. The colonel who visits Bartle's platoon describes being at war as doing 'great violence in the cause of good' (Powers 2013, 87). He gives them a comforting and brutal speech. He comforts them by 
assuring that they are there to impose 'God's justice' (87). However, he is fiercely honest when he informs them that they may have to pay with their own lives to enact that justice. Such a deep scepticism exists towards warfare in contemporary societies (Coker 2007). Even as Bartle narrates this episode, he is not blinded by the gesture: 'I was moved then, but what I now recall most vividly about that speech was the colonel's pride, his satisfaction with his own directness, his disregard for us as individuals' (Powers 2013, 87) This gesture is a public display of a resolute and unyielding nature in the face of war. However, these aspects of heroism are lost on the soldiers who question their 'destinations and purpose' (91). Although 'heroism feels and never reasons' (Emerson 1908), soldiers in the post-heroic times reason and ask for justifications. They are no longer naïve heroes who are willing to sacrifice their lives for redundant slogans (Ryan 2014). The novel disparages such a contradictory language that encourages soldiers to go to their death. In such a context, the narrative illustrates the 'crisis of heroism' (Becker $2007,7)$ amongst young soldiers who are no longer charged with heroic stories of sacrifice and bravery, rather with the need to survive.

Unlike Updike who considers the war on Iraq as a salvation for Iraqis (Alosman et al. 2019), Powers is certain only of the impact of war on all who participated in it. His note at the end of the novel clearly establishes the context for the narration of The Yellow Bird: 'Though I hope I've told one small part of the truth about the war, what I've written is not meant to report or document, nor is it meant to argue or advocate. Instead, I tried with what little skill I have to create the cartography of one man's consciousness, to let it stand ... as my reminder' (Powers 2013, 3). Through Murphy, who struggles to make sense of the senseless killing that he sees daily at Al Tafar, Powers questions the extent by which war changes a person's humanity. Murphy's need to see 'gentleness and kindness' (165) that he once experienced back home, causes him to visit the "HQ medics' unit" (161) daily to observe the emotional effect of death on a particular nurse. However, the private eventually loses his mind when the nurse also dies in a mortar attack on the medical facility. The novel problematises the post-heroic stance of being a soldier in contemporary times. Murph symbolises the soldiers who enlisted with the hope of making a difference, only to be brutally awaken to the irony of war.

To denounce war and draw attention to its irrationality, Bartle ridicules the fact that Murph has 'been butchered in the service of his country in an unknown corner of the world' (Powers 2013, 206). He also mocks how Murph's body would be received with 'the thanks of a grateful nation' (207). Powers' soldiers do not appreciate being killed in war as Max Weber (2004) claims. Similar to Bartle, Joe Bonham, a First World War soldier in Dalton Trumbo's celebrated novel, Johnny Got His Gun (2007), does not believe that dying for his country is worthwhile. Both soldiers of Powers and Trumbo are reluctant to accept the reasons behind these wars.

\section{Conclusion}

Throughout The Yellow Birds, death appears to be the most recurrent theme in war. Death in this context is not the honourable end of a brave soldier but an abominable scene of misery and dishonour. Soldiers are victims and primarily the tools of war and death. They are turned into merciless murderers. 
Similar to civilians, soldiers are afraid of death and are obsessed with their survival. For Bartle, experiencing a cruel war is not heroic but a shameful act. War is not a place where people ascertain their chivalrous qualities or morals but an immoral landscape of sin and sinners.

Through the narration of death, Powers includes Iraqis and Americans within the same category of 'us', thereby signifying the victims of the ongoing war on Iraq (Powers 2013, 4). Although thousands of Iraqis have been killed in September 2004, only less than a thousand American soldiers have been casualties in 'the war' (4). He also relates the number of Iraqi and American casualties, thereby further reflecting the disastrous face of war. All that have witnessed any aspect of war do not remain intact (Coker 2014).

Powers' post-heroic depiction of war in Iraq leaves a sense of shame and remorse in the hearts and minds of those who survived it. Murphy tells Bartle, 'I' m never going to tell anyone I was here when we get back home' (Powers 2013, 164). Nothing around war seems to be intact. The theatre of war is no more than a stage where heroic deeds or glorious acts are witnessed. War is a ground for worthless slaughter and reckless devastation. Fear, spitefulness and mercilessness are the chief attributes of war, rather than bravery and gallantry. The war, a figurative greedy monster, is depicted as the only beneficiary. Through the abstraction of war, all the people appear to be its victims, be it young children, old men, women or soldiers. We can see the trivial weight of human life. The Yellow Birds is a scream against the injustice of war and reprimands the issue against war farers and propagators. 


\title{
التصوير ما بعد البطولي للحرب في رواية كيفن بورز (العصافير الصفراء)
}

\author{
ريحانة محمد مايدين \\ قسم اللفة الإنجليزية، الجامعة الوطنية الماليزية، ماليزيا مايد \\ محمد إقبال محمد العثمان \\ قسم اللفة الإنجليزية وآدابها، جامعة ظفار، سلطنة عُمان
}

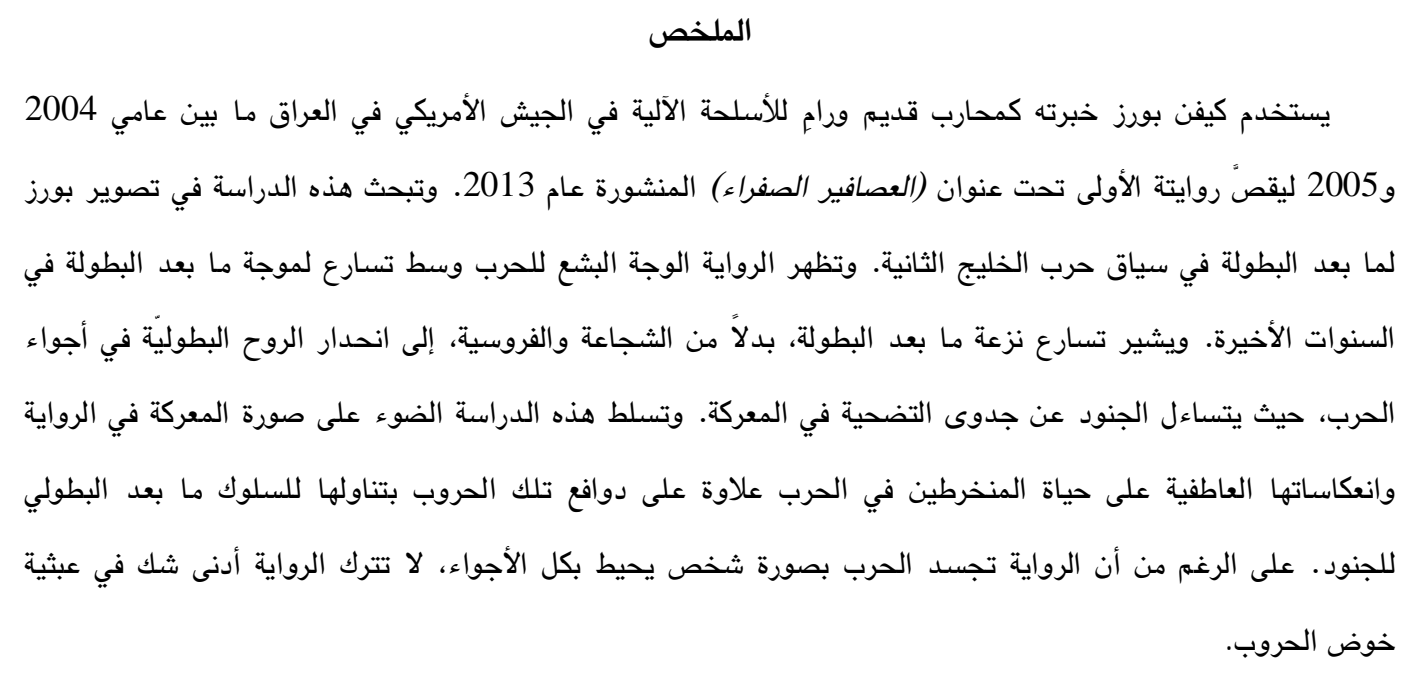

الكلمات المفتاحية: كيفن بورز، ما بعد البطولة، العصافير الصفراء، رواية الحرب. 
Post-Heroic Portrayal of War in Kevin Powers' The Yellow Birds

\section{References}

Alosman, Mohammad. Ikbal. M., Raihanah, Mohammad. M., and Ruzy Suliza Hashim. 2019. Colonial Shadows in John Updike's Terrorist. International Journal of Academic Research in Business and Social Sciences 9 (1): 1-17.

Becker, Ernest. 2007. The Denial of death. New York: Free Press Paperbacks.

Charles, Ron. 2012. The Yellow Birds, a novel of grit, grace and blood by an Iraq war veteran. The Washington Post. Retrieved April 20, 2019, from https://www.washingtonpost.com/entertainment/books/the-yellow-birds-a-novel-of-grit-grace-andblood-by-an-iraq-war-veteran/2012/09/25/f36a3966-01b8-11e2-b257

e1c2b3548a4a_story.html?noredirect=on\&utm_term $=.25870580$ ce 54

Coker, Christopher. 2002. Waging War Without Warriors? The Changing Culture of Military Conflict. Boulder: Lynne Rienner.

Coker, Christopher. 2007. The Warrior Ethos: Military Culture and the War on Terror. London: Routledge.

Coker, Christopher. 2014. Men at War: What Fiction Tells Us About Conflict, from The Iliad to Catch-22. USA: Oxford University Press.

Emerson, Ralph Waldo. 1908. Essays: Compensation, Heroism, Character, Nature. New York: G. Putnam's Sons.

Hawkins, Ty. 2014. “The Great War, the Iraq War, and postmodern America: Kevin Powers' The Yellow Birds and the radical isolation of today's US veterans." In The Great War in Post Memory Literature and Film. ed. Martin Löschnigg and Marzena Sokolowska-Paryz, 95-108. Berlin and Boston: De Gruyter.

Hemingway, Ernest. 1979. Men at War: The Best War Stories of All Time. New York: Random House.

James, William. 1971. The Moral Equivalent of War, and Other Essays. New York: Harper \& Row.

Luttwak, Edward N. 1995. Toward Post-Heroic Warfare. Foreign Affairs 74 (3): 109-22.

Lynn, John A. 2009. Battle: A History of Combat and Culture. London: Hachette.

Mann, Joelle. 2016. Mapping memory: Moving between Trauma and Terror in The Yellow Birds. Critique: Studies in Contemporary Fiction 58 (4): 340-350.

Mathonniere, Julien. 2014. War tales that blur the lines but extol the truth: How fiction helps make cogent war stories. WLA; War, Literature and the Arts 26: 1-9.

Nester, Thomas. 2013. Book review: The price of par. Bridgewater Review 32 (1): 39-40.

O'Gorman, Daniel. 2015. Refiguring difference: Imaginative geographies and "Connective Dissonance" in three novels of the Iraq War. Critique: Studies in Contemporary Fiction 56 (5): 545-559.

Powers, Kevin. 2013. The Yellow Birds. New York: Little, Brown and Company.

Precup, Amelia. 2017. Reversing absence. The explorations of memory in the Yellow Birds by Kevin Powers. Studia Ubb Philologia 62 (1): 173-190. 
Ryan, Cheyney. 2014. "The dilemma of cosmopolitan soldiering". In Heroism and The Changing Character of War: Toward Post-Heroic Warfare? ed. Sibylle Scheipers, 120-141. New York: Macmillan.

Scheipers, Sibylle. 2014. Heroism and the changing character of war: Toward post-heroic warfare? New York: Macmillan.

Smith, David Livingstone. 2011. Less than human. Why we demean, enslave and exterminate others. New York: Macmillan.

Smith, Hugh. 2005. What costs will democracies bear? A review of popular theories of casualty aversion. Armed Forces and Society 31 (4): 487-512.

Tait, Theo. 2013. The Hemingway crush. [Review of the book The Yellow Birds]. London Review of Books 35 (1): 10.

Trumbo, Dalton. 2007. Johnny Got His Gun. New York: Citadel.

Tyler, Lisa. 2001. Student companion to Ernest Hemingway. Greenwood Publishing Group.

Usbeck, Frank. 2018. Writing yourself home: US veterans, creative writing, and social activism. European Journal of American Studies 13 (13-2): 1-17.

Walter, Anke. 2016. What it felt like: Memory and the sensations of war in Vergil's Aeneid and Kevin Powers' The Yellow Birds. Thersites 4: 275-312.

Weber, Max. 2004. The Essential Weber: A Reader. London: Routledge. 